\title{
Towards the contemporary city. Reading method of post- unification restructuring of Trastevere in Rome
}

\author{
Giancarlo Salamone \\ Dipartimento di Architettura e Progetto. Università degli Studi di Roma "La Sapienza". Roma. \\ E-mail: giancarlo.salamone@uniroma1.it
}

\begin{abstract}
Trastevere, the only area of the historic center of Rome (together with the Vatican / Borgo complex) located on the right side of the Tiber river, shows a morphological structure that depends on the pre-existing substrate, both road that typological, which was modified during the post-unity period by the establishment of the Tiber fronts and, above all, by the opening of Viale Trastevere. In the way of thinking about urban morphology as a scalar product of the factors that influence each other, in particular building typology, local structure, overall structure and territory, and that contribute together to generate an organism, it is therefore possible to read this part of the historical center as the last product, but not definitive, of a "process". The reading method on the consolidated structure, later renovated in a post-unification era, is based on the analysis of the most abundant building typology and on the permanence and derivations of local typological processes that led to the formulation of the "line house" in nineteenth-century line, the predominant building type of roman expansion in nineteenth-twentieth century. The reading of the restructuring, understood as synchronic action on the historical center, has been implemented instead by the analysis of synchronic variations at "line house" through the research of all projects registered for the edification of each block. Thus we can see how the blocks resulting from the transformation, in the logic of a restructuring "contromaglia" like the one for the opening of Viale Trastevere, will be the result of the disconnection of the existing blocks in which the building type adopted has had to adapt to a lower return situations: a reading of a synchronic action on a diachronic process that gives us the modern morphological apparatus.
\end{abstract}

Keywords: Restructuring, Rome, Trastevere, process, reading method, tools, analysis in urban morphology

Introduction

Viale Trastevere, a post-unification axis that connects Ponte Garibaldi with the actual railway station, divides the Rione Trastevere in two different areas: the west side, that in this particular period shows receptive characteristics, and the east side that preserves intact its historical peculiarities. This difference depends on the different development the two areas have suffered in the period following the unification of Italy. Despite these different characteristics, the two areas are crossed by the same existing route, Via della Lungaretta, that connects Piazza Santa Maria in Trastevere with Ponte Rotto. This axis, the matrix path of the area structure, is closely connected with the others matrix paths of the Rione: Via della Lungara - that connects the Vatican with Santa Maria in Trastevere through Porta Santo Spirito and Porta Septimiana -, Via dei Vascellari/San Michele - that connects Porta Portese with Ponte Rotto -, and Via di San Francesco a Ripa - an eighteenth-century axis that connects Santa 
Maria in Trastevere with San Francesco a Ripa complex -. The predominant building type is the mature "Terraced house", the result of a process of tabernizzazione or insulizzazione of domus that came from the imperial structure and leads, through intermediate stages, to the pre-unification local morphology. These intermediate stages are represented by "case a profferlo", "case a corte", "case con portico", that together have led to the formation of the predominant roman building type. In the way of thinking about urban morphology as a scalar product of the factors that influence each other, in particular building typology, local structure, overall structure and territory, and that contribute together to generate an organism, it is therefore possible to read this part of the historical center of Rome as the last product, but not definitive, of a "process".

The action of transformation understood as restructuring of consolidated area sees the intervention fit within a context in which there is a two-way nature of the relationship between three dimensional stages: the single house - or rather a particular way of doing homes in a particular period and in a particular place, result of a diachronic process - influences the block as well as the block influences the single house; the block affects the local structure as well as the local structure, especially if undergoing renovation, affects the block; the local structure, viewed as a subset of the city, influences the city as well as the city influences the local structure; finally the single house influences the city as an organism and vice versa.

Through the analysis of the most abundant building typology and of the permanence and derivations of local typological processes, we can understand how the lapse of time between the last years of the temporal power until the conquest of Rome will mean the affirmation of a "multi-family raising" process of individual houses in terms of elevation, recast and restructuring of individual sectors, as a symptom of the evolution of society and as fundamental basis for the affirmation of the building type undisputed master of Rome unification: "la casa in linea" according to the nineteenth-century intentionality" that will be adopted as basic type for contromaglia restructuring of the area, represented by the opening of Viale Trastevere and generating the synchronic variations to the building type.

Unlike what has happened to the post-unification expansion tissue in which the fund structure built underlies the design of the block as the unit of constructed for the allotment for the opening of the Viale Trastevere we are still facing a restructuring with all that implies in terms of sizing. The axis, until the interception of Gianicolensi walls, dwells in a north-south direction within the constructed perpendicularly to the west-east existing axis, crossing each time areas of differentiated shape and age: the area of Via della Lungaretta; the area of saturation and creating a new "pole" related to operations, implemented under the pontificate of Pius IX, concerning the construction of the Tobacco Factory, the Mastai square and the basic building tissue originated from this sector; the seventeenth-century axis area of Via San Francesco a Ripa, with its segment of mature "terraced house" and already recast for the formation of online types according to the "nineteenth-century intentionality", and the area of complex to the south of San Cosimato. A "contromaglia" restructuring generates synchronic variations that are «[...] the application of a same type, of the same "concept of home" in abnormal situations compared to those more appropriate to the type producing therefore "lower return" buildings $[\ldots]$...

\section{Methodology}

Understanding the real significance of the operations made in post-unification period within the historic fabric of the Trastevere area needs as a fundamental tool, the analysis of the formation process of the local structure and of the building typology. This type of "transformation", in its distinction of being a general action implemented in a defined lapse of time - although in the case of the opening of Viale Trastevere we will see what this time appears dilated in a 60/70 year period for logistical internal reasons - can be defined as an anthropic intervention caused by a number of contingencies within a context or "environment" as a product with global organic unity characteristics. These "peculiarities" are caused by the 
fact of being the result of a prolonged process in history. This "global organic", in the case of Rione Trastevere, is the result of centuries of tissue formation and growth at the same time with the foundation and blossoming of specialized complexes which in this case will constitute a series of "polarity", when read in the local reading scale, and "nodality", if read in the reading scale that takes into account the urban aggregate as a whole. Consequently, the analysis of the built took into account a series of specific steps that in their diachronic development and their connection characteristics between close periods have led to today's figurative, typological and structural area "form".

To carry out the study, a number of cartographic tools have been used in order to reconstruct the "formation history" of the context. First of all we can mention the historical planimetric maps that we can define useful for "diachronic understanding of the whole" through the tissue analysis implemented in synchronous manner as regards the period after the sixteenth century: the maps of Rome of Leonardo Bufalini (1551), Mario Cartaro (1576), Antonio Tempesta (1593), Giovanni Maggi (1625) and Giovanni Battista Nolli (1748). Within these maps there is certainly the most valid and precise instrument and it is placed within this category only because it lacks the size and nominal specifications of the individual properties. Subsequently the "punctual synchronic understanding" tools such as the Land Registry Pio-Gregorian and plants collected by Professor Ermanno Polla, useful not only for understanding the general structure of the area but also the typological characteristics and nominal size of the individual properties surely resulting from trim paths of Trastevere. In particular, having identified the texture of the fabric not only at the time of preparing the land registry Pio-Gregorian but also to its preunification next update we can found the various expropriated particles, demolished and / or processed - including appliances - to allow 'opening of Viale Trastevere in order to quantify in terms of geometric-dimensional view of the various lots intended as the laying of the various synchronic variations on the type used and to recognize, through these features, the typological and formation tissue system.
After reading the typological process related to the building's consistency in its demolished and surviving parts the results of archival research will be exposed at the Capitoline Historical Archive.

\section{Measurement and analysis}

Until the first half of the nineteenth century, the analysis of the Gregorian Catasto and their brogliards give us, from all the fabric analyzed in this research, a single-parent consistency with poor melting of the properties. Most cadastral units seem to follow the dimensional characteristics in terms of depth and road width, relative to the types of houses from which they are derived. The length on the road stands on the size of the single cell - with the exceptions due to the synchronous variants to the carrier type, such as houses built on corner batches, restructure or clogging - and the depth ranges from single cell to double cell depending on Type with the possible addition of a front portico / loggia or as a witness to the type of "derivation" or as a witness of a type not modified in a procedural manner. The functional characteristics associated with the number of plans reported by the brogliards give us a basic construction compartment, normally consisting of only two floors, one of which is for residential use and the other for "shop" or "granary" use, property of a popular social class incapable, for lack of capital, to "rent" or "raise". A change can be seen through the consultation of the Capitoline Historical Archives. In relation to a series of cadastral units, related in particular to the paths of Via della Lungara, Via della Lungaretta - albeit limited - , via San Francesco a Ripa, Via dei Vascellari / Via San Michele and the Ponte Sisto area, a number of instances are filed for "restoration and erection" in the period from the middle of the eighteenth century to the capture of Rome. In fact, these operations can be recorded as "multifamily raising" processes of units that, being the result of a "distinct" typological process, contribute to "distinct" typological results. In the area of Ponte Sisto there are several processes of "multi-family raising" of mature 
"schiera" houses through the increase of the second cell in the inner area; in the area of Via della Lungara and Via di san Francesco in Ripa, instead, it is possible to find "multi-family raising" processes by merging and raising two mature "schiera" houses with displacement of the stairwell and possible partial loss of appearance in the interior area. In fact, this process, although apparent in the Trastevere Rione in many synchronous variants, leads to maturation of the typological process relating to the formation of the "line house", the "supporting" type of residential housing project from the eighteenth-century expansion phase. It is very important to note the advent of the "intentionality" of the nineteenth-century project relating to "line house" modification / redesign. Most of the reconditioning interventions involve not only a variation of the stairwells and of the horizontal and vertical distribution apparatus, but also a substantial change in the figurative apparatus expressed by overlapping the "critical and intentional" intervention of the architect / engineer on the results of the typological process: the introduction of the rhythmic wall, the axiality and symmetry, and the plan hierarchy. Unlike what has happened to the post-unity expansion fabric where the building compartment undergoes the design of the block as a unit of measure of constructed as regards the parcelling for the opening of viale Trastevere we are still faced with a restructuring with all the features of sizing. The restructuring axis, up to the interception of the Gianicolensi walls, extends north-south orthogonally to the pre-existing west-east route through different forms of conformation and era: the Lungaretta area; the area of saturation and the creation of a new "pole" related to the operations made under Pius IX pontificate concerning the construction of the Tabacchi Manifacture, of the Mastai Square and of the basic building fabric originating from this sector; The area of the seventeenthcentury axis of Via San Francesco in Ripa, with its suburb of mature "schiera" houses, and the area of the complex south of San Cosimato.

Thanks to the consultation of a series of documents stored in the Capitoline Historical Archives it is possible to reconstruct from the chronological and causal point of view the history and structure of the opening of Viale
Trastevere. Despite a series of acts relating to "public utility" expropriations stemming from the plans of 1873 and 1883 indicate the properties through which the new axis will have to pass the first settlements and constructions take place in those areas where the "machinability" of the expropriation sector did not have to consider the existing buildings: the south part of Via San Francesco in Ripa on the east side of today's Viale Trastevere. The history of the restructuring is divided into:

all the operations involved in the opening of a "road to Trastevere Station" which could be subdivided into the first buildings on the south side of Piazza Mastai on the east side of the postunit axis (1887), in the "section" of the existing block at Piazza Sonnino (1891), in the construction of "specialist" buildings in the part towards the Gianicolensi walls, practically coexisting with the "compensation" of the blocks on the west side of Viale Trastevere at Piazza Mastai (1907 and 1914) and in the dimensional and functional redefinition of the blcok of Via San Gallicano / Viale Trastevere / Vicolo Mazzamurelli (1921);

all the operations relating to the opening of a square - first Piazza d'Italia and later Piazza Giuseppe Gioacchino Belli - tangent to the planned Lungotevere and in front of the new Garibaldi Bridge (demolition and erection between the nineteenth and twentieth centuries); all the operations relating to the arrangement of the space in front of San Crisogono, today's Piazza Sonnino, divided by the square of Italy to which it was joined in the first plans - which caused the retention of the Anguillara Tower used in the first Years of the twentieth century to host the "House of Dante" (from the first decade of the twentieth century to the immediate postwar period).

Although we are in front of basic building, the formal and figurative apparatus is inspired by the vocabulary of the Roman special building which in second instance influences the typological organism in its construction and functional distribution.

We can assume it as an "ideal carrier" - ideal because most of the buildings are a synchronous variant of the same carrier type - for the formation of the postunitary apparatus for the restructuring of the ward the "casa in linea" 
with a symmetry axis with a double structural organism consisting of three parallel portions parallel to the facade, two exterior and one intermediate and with transversely opposite scaffold walls (barycentric and double ramp). The triple-body distribution system with the baricentric entrance-corridor system in the second deep bay and usually longitudinal to the road front serves the two zones, night and day, hierarchized according to the appearance.

\section{Conclusion}

Postunit interventions in preunit Rome can be summarized in demolitions for "enlargement or opening of roads" for mutated / added polarity. The first category - the enlargement of existing roads or paths - makes it easy to perceive the immediate "yield" of the use of a "type" in non-anomalous situations. Among these "restructurings" it is possible to include, although in part, the opening of Corso Vittorio Emanuele II with all qualitative appreciation already in the "giovannian" era. Relatively to the second category, it is possible to find the adaptation of a predetermined "type" within an anomalous situation, which produces a less productive product: a synchronous variant. In this category of intervention it is possible to include a series of operations carried out in the "inherited" constructed one of the most important, for the strength and the effects it has caused, surely represented by that complex of works and actions that have led to Opening of Viale Trastevere.

This restructuring has caused the structural and dimensional synchronous "reformulation" of the block, which instead, within a diachronic training process, is "self-made" according to the various competing factors to form the urban organism in its entirety; the adaptation of the type of construction "in linea" with the nineteenth-century intentions to anomalous building areas and therefore producing synchronous variants to the carrier type assumed; the involvement of a series of contingent factors, such as the public interest or, more often, the interest of the individual, which overall affect the body.

The analysis of the individual buildings of Viale Trastevere carried out through the consultation of the individual projects deposited was taken to fully understand the causes and results of the "formulation" of the synchronous variants.

The result is a series of criticalities that necessarily arise from the "formulation" of a synchronous variant adopted on "contromaglia" restructuring.

These criticalities in a diachronic process are self-crushing. The current legal apparatus also protects these anomalous areas because they are now considered "historical". The aim of the research was to "read" the causes and effects of a restructuring to identify possible "critical" correctional areas. 

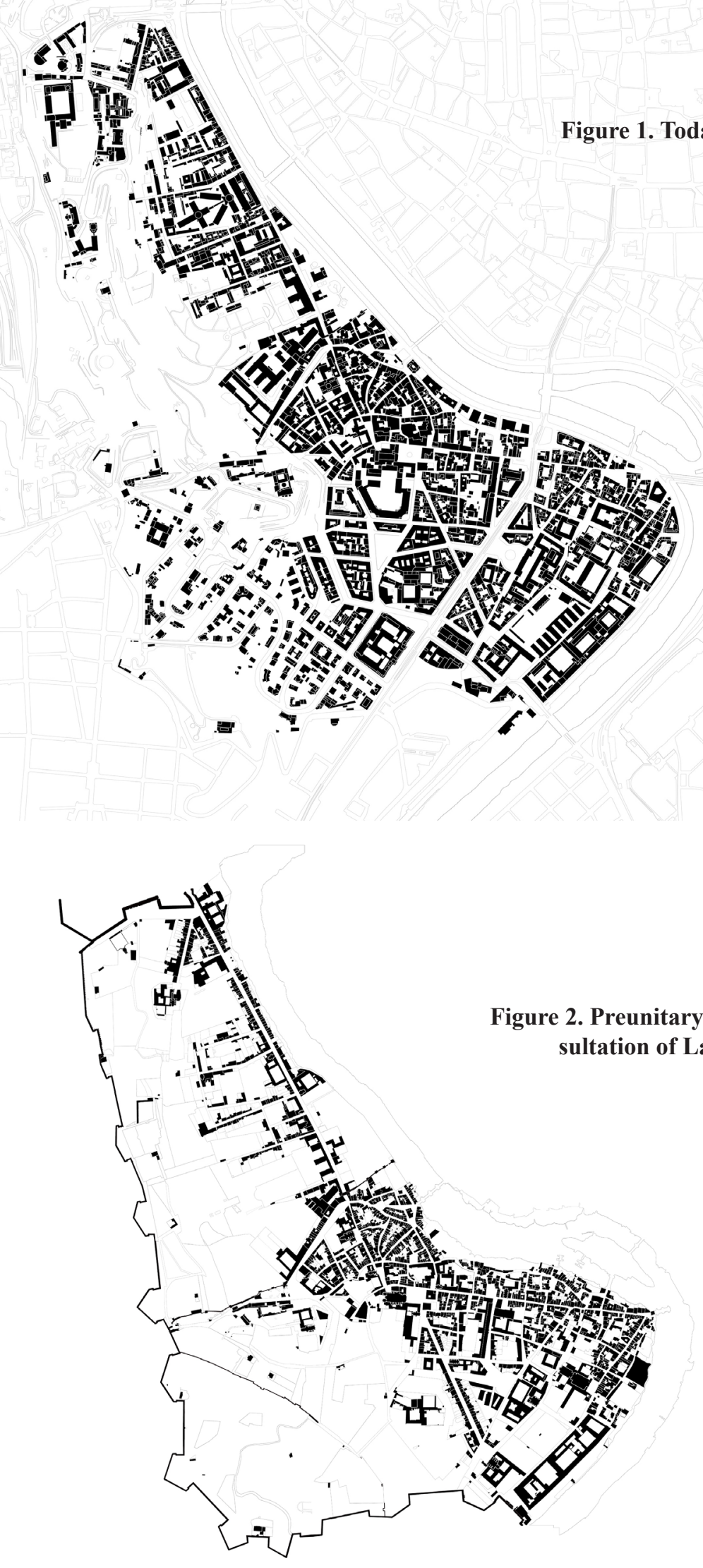

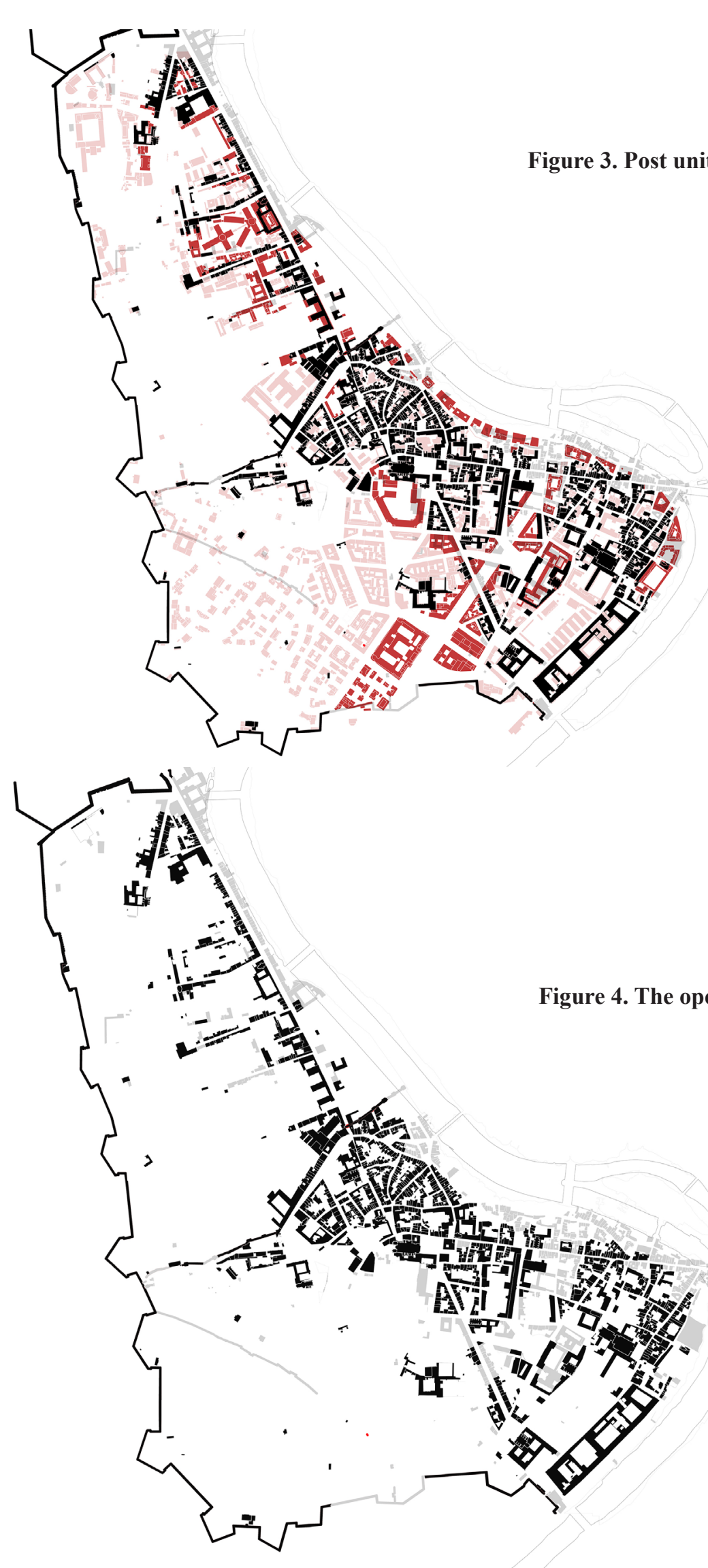


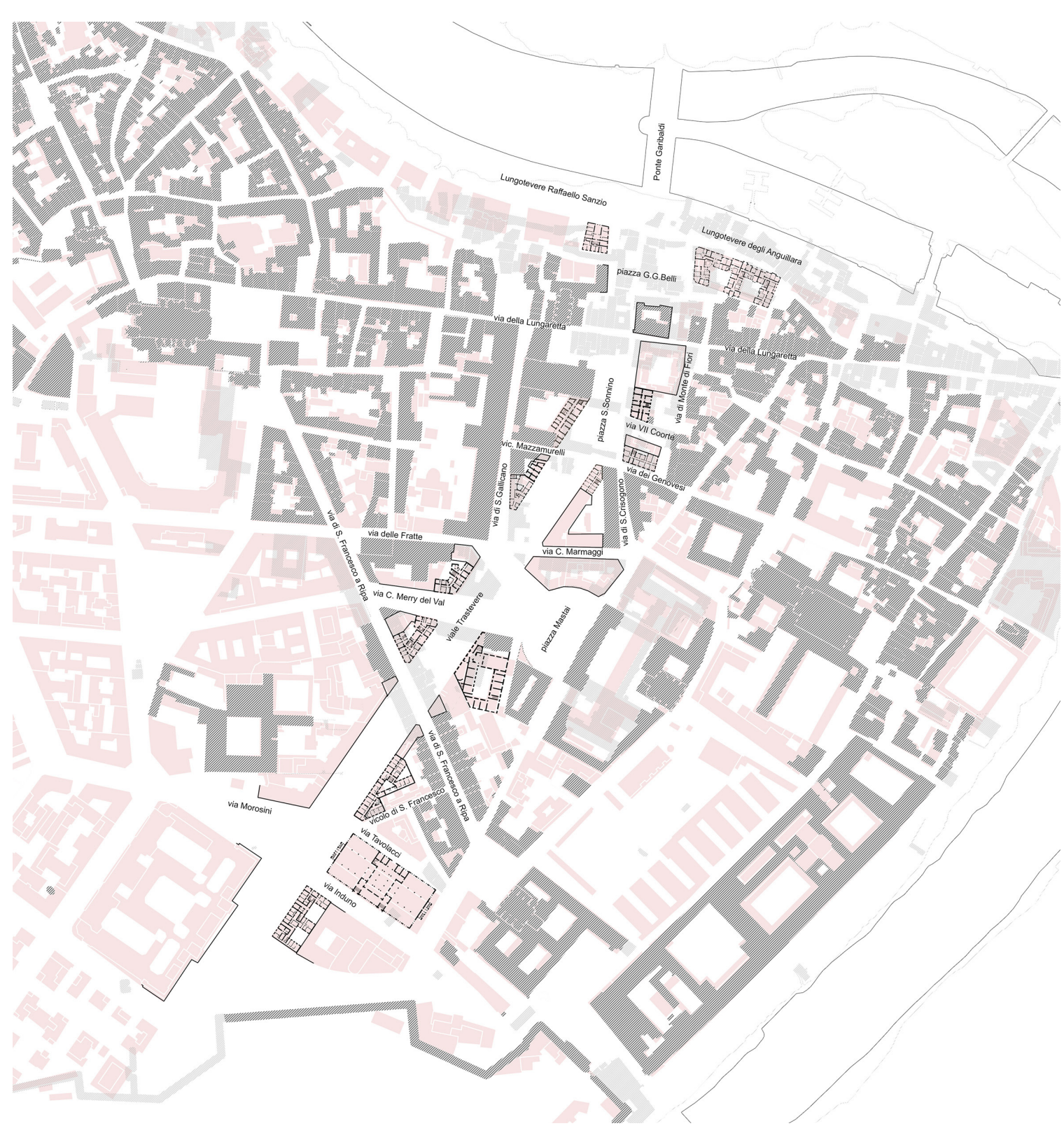

Figure 5. Post Unit buildings of Viale Trastevere

\section{References}

Bascià L., Carlotti P., Maffei G.L. (2000) La casa romana nella storia della città dalle origini all'Ottocento (Alinea, Firenze).

Benevolo L. (1971) Roma da ieri a domani (Laterza, Bari).

Benevolo L. (1977) Roma oggi (Laterza, Bari). Benevolo L. (1992) Roma dal 1870 al 1990 (Laterza, Bari).

Caniggia G. (1976) Strutture dello spazio antropico. Studi e note (Alinea, Firenze).

Caniggia G., Maffei G.L. (1979) Composizione architettonica e tipologia edilizia. 1_Lettura dell'edilizia di base (Marsilio, Venezia).

Caniggia G., Maffei G.L. (1984) Composizione architettonica e tipologia edilizia. 2_Progetto nell'edilizia di base (Marsilio, Venezia).

Caniggia G. (1986) La casa e la città dei primi secoli (Marsilio, Venezia).

Corsini M.G. (1998) Tipi e tessuti del centro storico di Roma. Lettura del costruito per il progetto (Edizioni Kappa, Roma).

Corsini M.G. (2001) Il tessuto e l'edilizia progettati in Italia dal 1870 al 1930. Permanenza e derivazioni dei processi tipologici locali (Edizioni Kappa, Roma). 
Corsini M.G. (2004) Palazzi romani: luogo e linguaggio (Edizioni Kappa, Roma).

Giovannoni G. (1931) Vecchie Città ed Edilizia nuova (Unione Tipografico Editrice Torinese, Torino).

Insolera I. (1962) Roma moderna (Einaudi, Torino).

Muratori S., Bollati R., Bollati S., Marinucci G. (1963) Studi per una operante storia urbana di Roma (Consiglio nazionale delle ricerche, Roma).

Muratori S. (1963) Architettura e civiltà in crisi (Centro studi di Urbanistica, Roma).

Spagnesi G. (1974) Edilizia romana nella seconda metà del XIX secolo (1848-1905), (DAPCO, Roma).

Strappa G. (1995) Unità dell'organismo architettonico: note sulla formazione e trasformazione dei caratteri degli edifici (Dedalo, Bari).

Vaccaro P. (1968) Tessuto e tipo edilizio a Roma dalla fine del XIV secolo alla fine del XVIII secolo, (Centro di studi di Urbanistica, Roma).

Vaccaro P., Ameri M. (1984) Progetto e realtà nell'edilizia romana dal XVI al XIX secolo (Edizioni Calosci, Cortona). 